\title{
Safety and Efficacy of Hepatitis B Vaccine in Hospital Personnel
}

\author{
Yasuyuki Arakawa, Shuichi Amaki, Masatoshi Mryamoto, \\ Yutaka Matsuo, Toshio Honda and Toshio Shikata*
}

\begin{abstract}
Clinical trials of the hepatitis B vaccine developed in Japan were performed by the phase I, phase II and phase III studies. It was found that this vaccine did not only contained HBV itself but also other pathogens. It was ascertained to be adequately safe, since no major side effect was induced. After inoculation of the vaccine 3 times into 195 hospital employees, an HBs antibody seroconversion rate of $91.8 \%$ $(97.0 \%$ in females and $86.3 \%$ in males) was obtained. In recipients aged more than 50 years, the rate was significantly lower. Although $8.2 \%$ of the recipients were non-responders to the vaccination, there was no significant correlation between the strength of the HBs antibody response and the lymphocyte subsets in the peripheral blood. It was observed, however, that among the non-responders, the incidence of low $\mathrm{OKT}^{+} / \mathrm{OKT}^{+}{ }^{+}$cell ratios tended to be somewhat increased. In follow-up studies of the antibody, majority of subjects, in whom the antibody level at 1 month after the 3 inoculations was below 50 RIA units, demonstrated negative conversion within 1 or 2 years. Namely, their value were reduced to below the minimal protective antibody value for prophylaxis of $\mathrm{HBV}$ infection.
\end{abstract}

Key Words: Hepatitis B, Hepatitis B vaccine, Immunogenicity, Clinical trials.

For immunological prophylaxis against hepatitis $B$ virus (HBV), we have the passive immunization method with HBIG and the active immunization method using hepatitis $B$ vaccine (HB vaccine). The former method has already achieved wide success in its extensive and practical use for the prophylaxis of $\mathrm{HBV}$ infection in cases of accidental infection among those engaged in the medical profession, or in vertical infection between mother and child. However, the former method should, by all means, be used transiently for emergencies.

It is important for long-term preventive measures against infection with $\mathrm{HBV}$ to induce permanent immunity by inoculation of $\mathrm{HB}$ vaccine. The development of $\mathrm{HB}$ vaccine represents an epochmaking accomplishment since it not only prevents
type-B hepatitis as an infection, but can also eventually prevent primary liver cell carcinoma.

In order to confirm the safety and effectiveness of the $\mathrm{HB}$ vaccine developed in Japan, clinical trials were performed with the vaccine, using persons engaged in the medical profession.

\section{MATERIALS AND METHODS}

\section{Subjects}

The subjects into whom HB vaccine was inoculated in the first, second and third phase studies consisted of 205 healthy hospital staff members who were HBs antigen negative, including physicians, nurses and other medical personnel working for Nihon University Hospital (Table 1). The status of serum HBV markers indicated 190 persons as seronegatives, 5 persons as positive for

From the Third Department of Internal Medicine and *the Department of Pathology,

Nihon University School of Medicine, Tokyo.

Received for publication July 15, 1985.

Reprint request to: Yasuyuki Arakawa, MD, The Third Department of Internal Medicine,

Nihon University School of Medicine, 30 Ohyaguchi Kamimachi, Itabashi-ku, Tokyo 173, Japan. 
Table 1. Characteristics of the subjects.

\begin{tabular}{lcccc}
\hline \multirow{2}{*}{ Characteristic } & \multicolumn{4}{c}{ Study Groups of HB Vaccine Trials } \\
\cline { 2 - 5 } & Phase I & Phase II & Phase II & Total \\
\hline No. Inoculated & 6 & 45 & 154 & 205 \\
Sex & & & & \\
Male & 6 & 24 & 74 & 104 \\
Female & 0 & 21 & 80 & 101 \\
Age (Years) & & & & \\
Male & & & & \\
$\quad$ Range & $27 \sim 59$ & $20 \sim 55$ & $22 \sim 51$ & \\
$\quad$ Mean & 41.8 & 31.8 & 30.8 & \\
Female & & & & \\
Range & & $19 \sim 56$ & $20 \sim 61$ & \\
Mean & & 36.9 & 31.5 & \\
HBV Status & & & & 190 \\
Seronegative & 2 & 37 & 151 & 190 \\
HBc Ab Alone & 0 & 2 & 3 & 5 \\
HBs Ab Positive & 4 & 6 & 0 & 10 \\
HBs Ag Positive & 0 & 0 & 0 & 0 \\
\hline
\end{tabular}

anti-HBc alone, and 10 persons as anti-HBs positive.

\section{HB vaccine}

The precipitated and inactivated $H B$ vaccine used in the present clinical trials for the first phase and second phase was prepared by the Hepatitis B Vaccine Development Council of the Japanese Ministry of Health and Welfare (MHW), and that for the third phase, by the Green Cross Corporation (Japan). As regards their compositions, both vaccines contained $40 \mu \mathrm{g}$ of $\mathrm{HBs}$ antigen protein per ml.

\section{Trial protocol}

The quantity of vaccine was $16 \mu \mathrm{g}$ for the first phase, $40 \mu \mathrm{g}$ for the second phase, and $20 \mu \mathrm{g}$ for the third phase, injected subcutaneously. In addition, at 4 weeks and at 20-24 weeks after the initial inoculation, the same quantities were injected.

\section{Clinical laboratory examinations}

Serum HBV-related markers and liver function tests (total bilirubin, GOT, GPT, LDH, Al-phos. and $\gamma$-GTP) were determined 3 times at each inoculation of vaccine, and at 1 month prior to the last inoculation.

HBs antibody was determined by the PHA method and the RIA method. In the former method, values of over $2^{2}$ (4-fold), and in the latter method, those of over 2.0 of the cut off index, were judged to be positive. $\mathrm{HBC}$ antibody was taken to be positive when the percent inhibition exceeded $70 \%$ in the RIA method.

Furthermore, the serum levels of antibodies to mumps virus, adenovirus 8 , herpes simplex virus, poliovirus 1 , measles virus, cytomegalovirus, rubella virus, coxsackievirus B1, RS virus, Japanese encephalitis virus and mycoplasmas, selected at random before inoculation of the $\mathrm{HB}$ vaccine and at 8 weeks after the inoculation, were determined by the complement fixation test, the level of antibody to Epstein-Barr virus (anti-CVAIgM) was determined by the indirect fluorescent antibody method.

\section{Peripheral blood lymphocyte subpopulations}

Analysis of the peripheral blood lymphocyte subpopulations was made by the laser flow cytometry method (Ortho Spectrum III), using the monoclonal antibody series of Orthomune (OKT3: anti-human peripheral T-lymphocyte antibody, OKT4: anti-human inducer/helper T-lymphocyte antibody, OKT8: anti-human suppressor/cytotoxic T-lymphocyte antibody, OKT1al: anti-human DR framework antibody).

\section{Side effects}

On the day following the inoculation of $\mathrm{HB}$ vaccine, interview forms for side effects were distributed to each inoculated person. The local reactions at the injected site and the systemic reaction were investigated.

\section{RESULTS}

\section{Anamnestic responses in HBs antibody carriers after inoculation of $H B$ vaccine}

Inoculation of $\mathrm{HB}$ vaccine twice with an interval of 1 month into 4 persons who already possessed HBs antibody before the inoculation who underwent the first phase study, and in 6 persons who underwent the second phase study, revealed a rapid rise in $\mathrm{HBs}$ antibody levels in both groups, an anamnestic response (Fig. 1). These findings indicate that the $\mathrm{HB}$ vaccine employed in the present study had sufficient antigenicity.

2. HBs antibody seroconversion rate in persons inoculated with $H B$ vaccine who were $H B s$ 

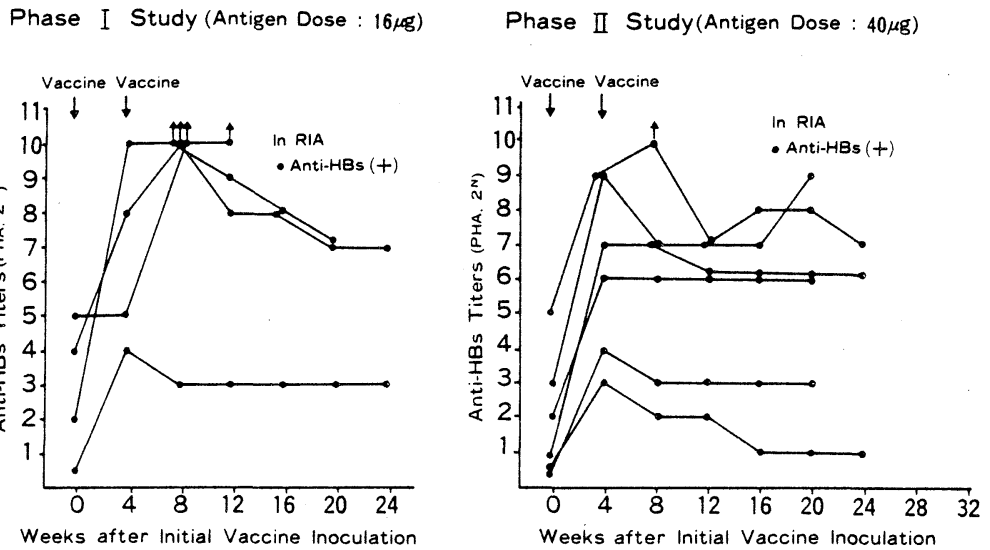

Fig. 1. Anamnestic anti-HBs response after $\mathrm{HB}$ vaccine inoculation in 10 anti-HBs-positive recipients.

\section{antibody negative}

In 2 persons inoculated with the vaccine who underwent the first phase study, seroconversion of HBs antibody was shown at 1 month after the second inoculation in 1 person (40 Y, male), and at 3 months after the third inoculation in the other (27 Y, male). The HBs antibody seroconversion rate at 28 weeks after the first inoculation in 39 persons who were inoculated with $\mathrm{HB}$ vaccine in the second phase study was $89.7 \%$ ( $84.2 \%$ for males and $95.0 \%$ for females). On the other hand, the HBs antibody seroconversion rate at 24 weeks after the initial inoculation in 154 persons who received the vaccine in the third phase study was $92.2 \%(86.5 \%$ for males and $95.0 \%$ for females). When the results of the first, second and third phase studies were combined, the mean seroconversion rate at 1 month after inoculation of the vaccine 3 times was $91.8 \%$ (Table 2). Although the seroconversion rate in females exhibited a slightly higher tendency than

Table 2. Cumulative incidence of anti-HBs responses after $\mathrm{HB}$ vaccine inoculation by age group in 195 anti-HBs-negative recepients in phase I, II and II studies.

\begin{tabular}{l|ccc}
\hline Age Sex & Male & Female & Total \\
\hline $10 \sim 19$ & - & $1 / 1(100.0 \%)$ & $1 / 1(100.0 \%)$ \\
$20 \sim 29$ & $46 / 50(92.0 \%)$ & $47 / 47(100.0 \%)$ & $93 / 97(95.9 \%)$ \\
$30 \sim 39$ & $27 / 33(81.8 \%)$ & $21 / 22(95.5 \%)$ & $48 / 55(87.3 \%)$ \\
$40 \sim 49$ & $8 / 10(80.0 \%)$ & $23 / 23(100.0 \%)$ & $31 / 33(93.9 \%)$ \\
$50 \leqq$ & $1 / 2(50.0 \%)$ & $5 / 7(71.4 \%)$ & $6 / 9(66.7 \%)$ \\
\hline Total & $82 / 95(86.3 \%)$ & $97 / 100(97.0 \%)$ & $179 / 195(91.8 \%)$ \\
\hline
\end{tabular}

that in males, no significant difference was observed.

Examination of the chronological changes in the seroconversion rate after inoculation of the vaccine showed that the rate was $18.5 \%$ after the first inoculation, $78.5 \%$ after the second inoculation and $91.8 \%$ after the third inoculation. When the distribution of HBs antibody values after the third inoculation was examined, it was found that among 195 subjects, $61.6 \%$ showed strong reactions of over 50 RIA units of HBs antibody (cutoff index), $14.9 \%$ showed low reactions within the range of 10-49.9 RIA units, $15.4 \%$ showed weak reactions within 2.0-9.9 RIA units and $8.2 \%$ showed nil reaction of less than 2.0 RIA

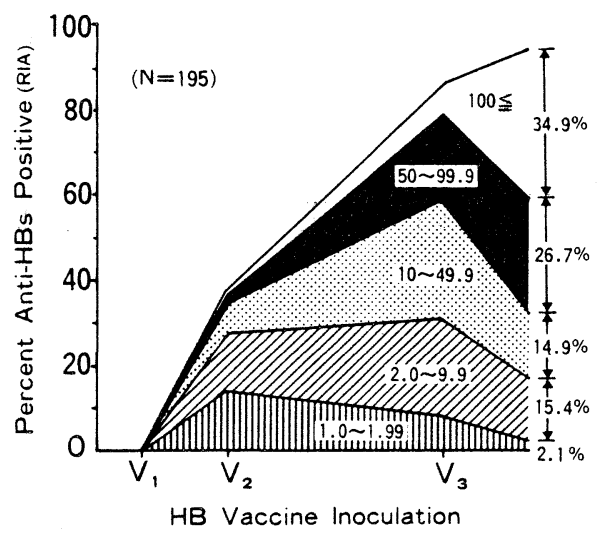

Fig. 2. Comparison of anti-HBs responses and distribution of RIA unit values after $\mathrm{HB}$ vaccine inoculation in 195 anti-HBs-negative recipients in the phase I, II and III studies. 
units. The ratio of subjects with high antibody values of over 50 RIA units thus rose markedly after 3 inoculations (Fig. 2). Conparison of the chronological changes in the seroconversion rate after the vaccine inoculation, as classified by sex, indicated no significant difference between the two sexes.

A similar comparison of the chronological changes in the seroconversion rate, as classified by age, revealed that the rates tended to be similar in each age group below 50 years of age. However, the rates in the age group of over 50 years were only $43.5 \%$ after 2 inoculations and $66.7 \%$ after 3 inoculations, and these rates were significantly lower than those in any of the younger groups $(\mathrm{p} \leqq 0.01)$.

3. Changes in $\mathrm{HBc}$ antibody levels and in those of antibodies to other pathogens before and after inoculation of $H B$ vaccine

There were no subjects who became positive for HBs antigen after inoculation of the HB vaccine. In 71 subjects in whom both $\mathrm{HBs}$ antibody and $\mathrm{HBC}$ antibody were shown to be negative before the vaccine inoculation, clearly indicating no previous $\mathrm{HBV}$ infection, the $\mathrm{HBC}$ antibody values in the blood before and after the vaccine were determined. Only 1 subject turned positive after the inoculation, with the value reaching over $70 \%$ transiently; none of the other subjects showed a significant rise in $\mathrm{HBc}$ antibody values throughout the study (Fig. 3). The levels of

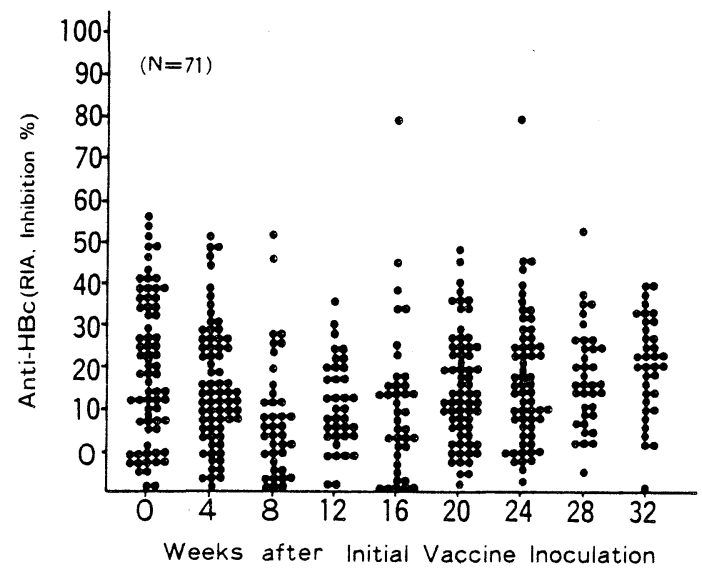

Fig. 3. Anti-HBc responses before and after $\mathrm{HB}$ vaccine inoculation in 71 recipients without previous exposure to $\mathrm{HBV}$ in the phase II and III studies. antibodies to other pathogens in 45 subjects also did not change significantly after the inoculation.

\section{Liver function tests and side effects}

Throughout the clinical trials, the liver function test values did not show any significant rise.

Repeated subcutaneous injections of vaccine amounting to a total of 149 injections in the first and second phase studies induced a very slight rise in body temperature to $37.4^{\circ} \mathrm{C}$ only once, as well as mild local pain in a few subjects, but no other major side effects were complained of. In the third phase study, however, repeated subcutaneous injections of vaccine (a total of 462 injections in 154 subjects) induced sore arm, general fatigue, feverish feeling and headache at rather high frequencies (Table 3 ).

5. Relation between HBs antibody reactions after $H B$ vaccine inoculation and the peripheral blood lymphocyte subpopulations

In a total of 144 subjects inoculated with $\mathrm{HB}$ vaccine, the acquired antibody (cut-off index) after 3 inoculations were divided into 3 groups consisting of a non-responder group with below 2.0 RIA units, a weak responder group with 2.09.9 RIA units and a good responder group with over 10.0 RIA units, and compared with the peripheral blood lymphocyte subpopulations (mean $\pm \mathrm{SD}$ ) (Fig. 4). No statistically significant

Table 3. Side effects after $\mathrm{HB}$ vaccine inoculation in the phase III study.

\begin{tabular}{lr}
\hline Signs \& Symptoms & \multicolumn{1}{c}{ Incidence * } \\
\hline Fatigue & $49(10.6 \%)$ \\
Feverish Feeling & $23(5.0 \%)$ \\
Headache & $17(3.7 \%)$ \\
Nausea & $8(1.7 \%)$ \\
Cold Feeling & $6(1.3 \%)$ \\
Diarrhea & $5(1.1 \%)$ \\
Abdominal Pain & $4(0.8 \%)$ \\
Fever & $2(0.4 \%)$ \\
Local Complaints & \\
Sore Arm & $63(13.6 \%)$ \\
Erythema \& Induration & $11(2.4 \%)$ \\
Feverish Feeling & $6(1.3 \%)$ \\
Itching & $1 \quad(0.2 \%)$ \\
\hline * No. of total injections: 462
\end{tabular}



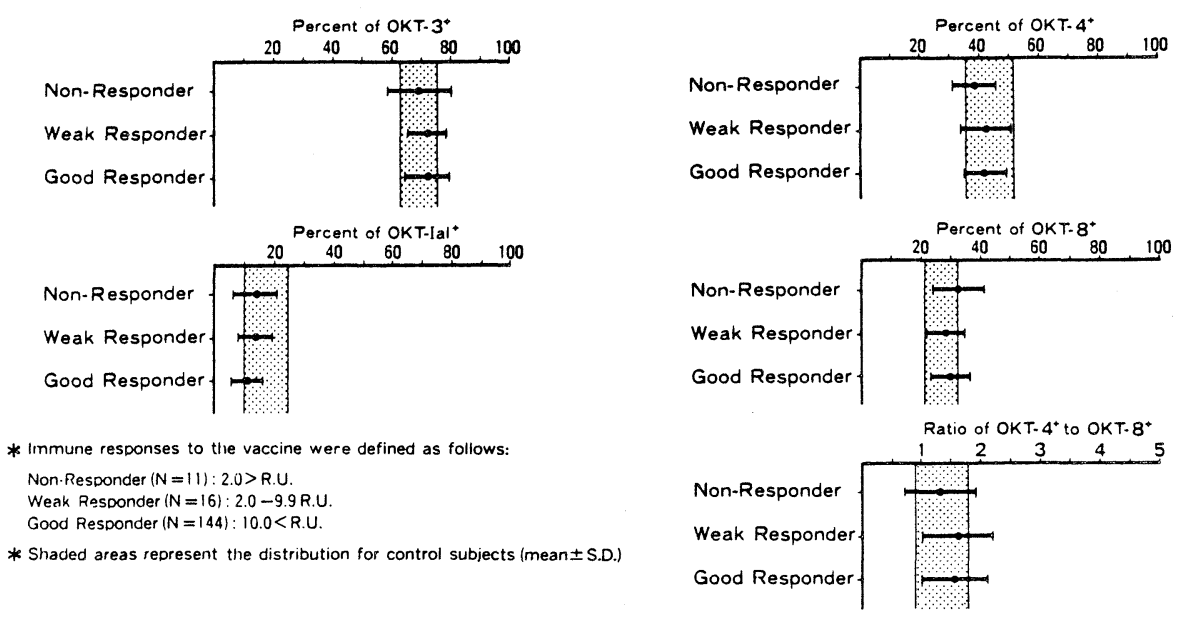

Fig. 4. Relationship between peripheral lymphocyte subpopulations and anti-HBs responses after 3 injections of $\mathrm{HB}$ vaccine.

differences in $\mathrm{OKT}^{+}$cells, OKT $4^{+}$cells, OKT $8^{+}$ cells and OKT1 $\mathrm{al}^{+}$cells, were noted among the 3 groups. In the non-responder group, however, as compared with the other 2 groups, the number of $\mathrm{OKT}_{4}{ }^{+}$cells was somewhat small, whereas the number of $\mathrm{OKT}^{+}$cells was larges. The ratio of $\mathrm{OKT} 4^{+} / \mathrm{OKT} 8{ }^{+}$cells was thus below 1.0 in $4 / 11$ in the non-responder group, as compared to $3 / 16$ in the weak responder group and 16/117 in the good responder group. Conversely, the ratio of $\mathrm{OKT}^{+}{ }^{+} /$ $\mathrm{OKT}^{+}$cells was over 2.0 in only $1 / 11$ in the nonresponder group, as compared to 4/16 in the weak responder group and 19/117 in the good responder group.

\section{Follow-up studies of the acquired antibody after inoculation of $H B$ vaccine}

Table 4 shows the changes in acquired antibodies at 2 years and 3 years after inoculation of the vaccine 3 times, in subjects inoculated with the $\mathrm{HB}$ vaccine in the second phase study. Table 5 shows the changes in acquired antibodies at 1 year and 2 years after inoculating the vaccine 3 times, in subjects inoculated with the $\mathrm{HB}$ vaccine in the third phase study.

At 2 years after the second phase study, $17.6 \%$ of the subjects, in whom the HBs antibody had turned positive became negative, and the rate of reduction of the mean antibody level was $50.8 \pm 46.1 \%$, while at 3 years $31.3 \%$ of them had become negative, and the rate of reduction
Table 4. Follow-up of anti-HBs levels in vaccine responders with different initial anti-HBs levels after 3 injections of $\mathrm{HB}$ vaccine in the phase II study.

(A) 25 months after the 3rd injection

\begin{tabular}{|c|c|c|c|c|c|c|c|}
\hline \multicolumn{2}{|c|}{7 Months } & \multicolumn{6}{|c|}{31 Months after Initial Inoculation } \\
\hline \multirow{2}{*}{$\begin{array}{l}\text { RIA } \\
\text { Range }\end{array}$} & \multirow{2}{*}{$\begin{array}{l}\text { No. of } \\
\text { Cases }\end{array}$} & \multicolumn{5}{|c|}{ RIA Range } & \multirow{2}{*}{$\begin{array}{l}\text { Percentage } \\
\text { Decrease }\end{array}$} \\
\hline & & $2.0>$ & $2.0-9.9$ & $10.0-49.9$ & $50.0-99.9$ & $100 \leqq$ & \\
\hline $2.0-9.9$ & 5 & $(60.0 \%)$ & $(40.0 \%)$ & & & & $\begin{array}{c}40.0 \\
\pm 1.3\end{array}$ \\
\hline $10.0-49.9$ & 0 & & & & & & \\
\hline $50.0-99.9$ & 9 & & $(11.1 \%)$ & $\stackrel{4}{4}$ & $\begin{array}{c}4 \\
(44.4 \%)\end{array}$ & & $\begin{array}{c}52.3 \\
\pm \\
26.9\end{array}$ \\
\hline $100 \leqq$ & 3 & & & & $(33.3 \%)$ & $\begin{array}{l}2 \\
(66.7 \%)\end{array}$ & $\begin{array}{c}65.7 \\
\pm \\
14.4\end{array}$ \\
\hline Total & 17 & $(17.6 \%)$ & $(17.6 \%)$ & $\begin{array}{c}4 \\
(23.5 \%)\end{array}$ & $\begin{array}{c}5 \\
(29.4 \%)\end{array}$ & $\begin{array}{c}2 \\
(11.8 \%)\end{array}$ & $\begin{array}{c}50.8 \\
\pm \\
46.1\end{array}$ \\
\hline
\end{tabular}

- Expressed as mean \pm S.D.

(B) 37 months after the 3rd injection

\begin{tabular}{|c|c|c|c|c|c|c|}
\hline \multicolumn{2}{|c|}{7 Months } & \multicolumn{5}{|c|}{43 Months after Initial Inoculation } \\
\hline \multirow{2}{*}{$\begin{array}{l}\text { RIA } \\
\text { Range }\end{array}$} & \multirow{2}{*}{$\begin{array}{l}\text { No. of } \\
\text { Cases }\end{array}$} & \multicolumn{4}{|c|}{ RIA Range } & \multirow{2}{*}{$\begin{array}{l}\text { Percent } \\
\text { Decrease }\end{array}$} \\
\hline & & $2.0>$ & $2.0-9.9$ & $10.0-49.9$ & $50.0-99.9 \quad 100 \leqq$ & \\
\hline $2.0-9.9$ & 5 & $(80.0 \%)$ & & $(20.0 \%)$ & & $\begin{array}{c}23.0 \\
\pm \\
135.4\end{array}$ \\
\hline $10.0-49.9$ & 2 & $(50.0 \%)$ & $\begin{array}{c}1 \\
(50.0 \%)\end{array}$ & & & $\begin{array}{c}94.1 \\
\pm \\
1.7\end{array}$ \\
\hline $50.0-99.9$ & 6 & & & $(100.0 \%)$ & & $\begin{array}{r}70.4 \\
\pm \\
6.9\end{array}$ \\
\hline $100 \leqq$ & 3 & & & $(100.0 \%)$ & & $\begin{array}{c}75.7 \\
\pm \\
14.5\end{array}$ \\
\hline Total & 16 & $\begin{array}{c}5 \\
(31.3 \%)\end{array}$ & $(6.3 \%)$ & $\begin{array}{c}10 \\
(62.5 \%)\end{array}$ & & $\begin{array}{c}59.5 \\
\pm \\
75.1\end{array}$ \\
\hline
\end{tabular}

- Expressed as meant S.D. 
Table 5. Follow-up anti-HBs levels in vaccine responders with different initial anti-HBs levels after 3 injections of $\mathrm{HB}$ vaccine in the phase III study.

(A) 13 months after the 3rd injection

\begin{tabular}{|c|c|c|c|c|c|c|c|}
\hline \multicolumn{2}{|c|}{6 Months } & \multicolumn{6}{|c|}{18 Months after Initial Inoculation } \\
\hline \multirow{2}{*}{$\begin{array}{l}\text { RIA } \\
\text { Range }\end{array}$} & \multirow{2}{*}{$\begin{array}{l}\text { No. of } \\
\text { Cases }\end{array}$} & \multicolumn{5}{|c|}{ RIA Range } & \multirow{2}{*}{$\begin{array}{l}\text { Percentage } \\
\text { Decrease }\end{array}$} \\
\hline & & $2.0>$ & $2.0-9.9$ & $10.0-49.9$ & $50.0-99.9$ & $100 \leqq$ & \\
\hline $2.0-9.9$ & 11 & $\begin{array}{c}7 \\
(63.6 \%)\end{array}$ & $\begin{array}{c}4 \\
(36.4 \%)\end{array}$ & & & & $\begin{array}{c}64.7 \\
\pm \\
25.5\end{array}$ \\
\hline $10.0-49.9$ & 21 & $\begin{array}{c}5 \\
(23.8 \%)\end{array}$ & $(28.6 \%)$ & $(28.6 \%)$ & $(19.0 \%)$ & & $\begin{array}{c}38.2 \\
\frac{ \pm}{78.7}\end{array}$ \\
\hline $50.0-99.9$ & 32 & & $\left(\begin{array}{c}3 \\
9.4 \%)\end{array}\right.$ & $\begin{array}{c}14 \\
(43.8 \%)\end{array}$ & $\begin{array}{c}11 \\
(34.4 \%)\end{array}$ & (12.5\%) & $\begin{array}{c}28.7 \\
\pm \pm \\
50.5\end{array}$ \\
\hline $100 \leqq$ & 50 & & $(2.0 \%)$ & $(6.0 \%)$ & $\begin{array}{c}14 \\
(28.0 \%)\end{array}$ & $\begin{array}{c}32 \\
(64.0 \%)\end{array}$ & $\begin{array}{c}6.9 \\
\pm \\
42.6\end{array}$ \\
\hline Total & 114 & $(10.5 \%)$ & $\begin{array}{c}14 \\
(12.3 \%)\end{array}$ & $(20.2 \%)$ & $\begin{array}{c}29 \\
(25.4 \%)\end{array}$ & $\begin{array}{c}36 \\
(31.6 \%)\end{array}$ & $\begin{array}{c}24.7 \\
\pm \\
54.7\end{array}$ \\
\hline
\end{tabular}

(B) 25 months after the 3 rd injection

\begin{tabular}{|c|c|c|c|c|c|c|c|}
\hline \multicolumn{2}{|c|}{6 Months } & \multicolumn{6}{|c|}{30 Months after Initial Inoculation } \\
\hline \multirow{2}{*}{$\begin{array}{l}\text { RIA } \\
\text { Range }\end{array}$} & \multirow{2}{*}{$\begin{array}{l}\text { No. of } \\
\text { Cases }\end{array}$} & \multicolumn{5}{|c|}{ RIA Range } & \multirow{2}{*}{$\begin{array}{l}\text { Percent } \\
\text { Decrease }\end{array}$} \\
\hline & & $2.0>$ & $2.0-9.9$ & $10.0-49.9$ & $50.0-99.9$ & $100 \leqq$ & \\
\hline $2.0-9.9$ & 9 & $\begin{array}{c}7 \\
(77.8 \%) \\
\end{array}$ & $(22.2 \%)$ & & & & $\begin{array}{c}67.9 \\
\pm \\
41.3\end{array}$ \\
\hline $10.0-49.9$ & 18 & $(61.1 \%)$ & $\begin{array}{c}5 \\
(27.8 \%)\end{array}$ & $(5.6 \%)$ & $(5.6 \%)$ & & $\begin{array}{c}80.8 \\
\pm \\
.38 .0\end{array}$ \\
\hline $50.0-99.9$ & 23 & $\begin{array}{c}4 \\
(17.4 \%)\end{array}$ & $\begin{array}{c}8 \\
(34.8 \%)\end{array}$ & $\begin{array}{c}5 \\
(21.7 \%)\end{array}$ & $(13.0 \%)$ & $(13.0 \%)$ & $\begin{array}{c}46.8 \\
\pm \\
89.7\end{array}$ \\
\hline $100 \leqq$ & 38 & $(5.3 \%)$ & $\begin{array}{c}10 \\
(26.3 \%)\end{array}$ & $\begin{array}{c}15 \\
(39.5 \%)\end{array}$ & $\begin{array}{c}11 \\
(28.9 \%)\end{array}$ & & $\begin{array}{c}75.2 \\
\pm \\
20.4\end{array}$ \\
\hline Total & 88 & $\begin{array}{c}24 \\
(27.3 \%)\end{array}$ & $\begin{array}{c}25 \\
(28.4 \%)\end{array}$ & $(23.9 \%)$ & $\begin{array}{c}15 \\
(17.0 \%)\end{array}$ & $\begin{array}{c}3 \\
(3.4 \%)\end{array}$ & $\begin{array}{c}68.2 \\
\pm \\
53.1\end{array}$ \\
\hline
\end{tabular}

of the mean antibody level was $59.5 \pm 75.1 \%$. In particular, among subjects whose acquired antibody levels were low or weak (below 50 RIA units), $50.0-80.0 \%$ had become negative at that time, whereas among subjects showing strong reactions with $\mathrm{HBs}$ antibody values of over 50 RIA units, none had turned negative.

At 1 year after the third phase study, $10.5 \%$ of the subjects who were positive for $\mathrm{HBs}$ antibody had become negative, and the rate of reduction of the mean antibody level was $24.7 \pm 54.7 \%$, while at 2 years $27.3 \%$ of them became negative, and the rate of reduciton of the mean antibody value was $68.2 \pm 53.1 \%$. In particular, among subjects whose acquired antibody levels were low or weak (below 50 RIA units), 61.1-77.8\% had become negative at that same period, whereas among subjects showing strong reactions, with HBs antibody values of over 50 RIA units, none had become negative at 1 year, and even at 2 years the figure was as low as $6 / 61(9.8 \%)$. However, the incidence of cases with values reduced to below 10 RIA units was $4.9 \%$ at 1 year, and $39.3 \%$ at 2 years.

\section{DISCUSSION}

Since 1975 , HB vaccines have been developed in many different countries ${ }^{1-4}$ ), and in the United States and France it is now recommended in routine practice. In Japan, manufacture of the vaccine and clinical trials with the vaccine were initiated in 1975 at the Science and Technology Agency, and were continued from 1976 onwards by the Hepatitis B Vaccine Development Council of the MHW. The authors joined the research project of the Hepatitis B Vaccine Development Council and conducted clinical trials with the $\mathrm{HB}$ vaccine. Efficacy trials of $\mathrm{HB}$ vaccines ${ }^{5-13)}$ in groups at a high risk of $\mathrm{HBV}$ infection have been reported for the Pasteur vaccine ${ }^{1,5-9)}$, the Merk vaccine ${ }^{10-12)}$, the NIAID vaccine ${ }^{13)}$ and the Netherlands vaccine ${ }^{3,4)}$. In these clinical trials $\mathrm{HBs}$ antibody was detected in $85 \%$ to $95 \%$ of vaccine recipients in studies conducted on medical staff members. However, care must be taken in making a direct comparison of these results, because the vaccine dose range from 3 to $20 \mu \mathrm{g}$ and the criteria for antibody response to the vaccine varied. On the other hand, in the first and second phase tests $^{14)}$ which have been completed in Japan, HBs antibody was induced in about $90 \%$ of the subjects. During third phase tests conducted on a large-scale in Japan, Suzuki et al. ${ }^{15)}$ found that in 2,052 persons the HBs antibody seroconversion rate (by the RIA method) was $21.7 \%$ at 4 weeks after the initial inoculation, $71.3 \%$ at 24 weeks, and $85.8 \%$ at 28 weeks, while Ichida et al. ${ }^{16)}$ observed that in 2,056 persons the seroconversion rate (by the PHA method) was $16.0 \%$ at 4 weeks after the initial inoculation, $59.8 \%$ at $20-40$ weeks, and $86.0 \%$ at $24-28$ weeks. The results in the present study accorded broadly with those observed in the previous large-scale third phase 
tests. It is quite clear also that neither set of results was inferior to those reported in Western countries. The HB vaccine developed in Japan is therefore considered to be sufficiently effective in such clinical trials.

Although some researchers ${ }^{17}$ ) have reported that the rate of seroconversion of HBs antibody by $\mathrm{HB}$ vaccine was higher when the dose was higher, and that there was no sex difference, other workers ${ }^{18,19)}$ have stated that doses of $20 \mu \mathrm{g}$ and $40 \mu \mathrm{g}$ produced no significant difference. In our study, no significant difference in the final HBs antibody seroconversion rate was found between the results of the second phase test using at least $40 \mu \mathrm{g}$, and those of the third phase test using $20 \mu \mathrm{g}$. Rather, it appeared that background factors, such as the age or sex of the inoculated subjects, exerted greater influence on the production of $\mathrm{HBs}$ antibody. Indeed, there have been many reports indicating that the capacity for HBs antibody production after inoculation of the vaccine was reduced in older subjects at high ages. The HBs antibody seroconversion rates in subjects at ages above 40 or 50 were $70 \%$ or thereabouts, and the figures were significantly lower than in younger subjects, whose seroconversion rates were $80 \%$ or above. This tendency was more marked in male subjects. Furthermore, an overall sex difference in rates of $\mathrm{HBs}$ antibody induction after inoculation of $\mathrm{HB}$ vaccine is clear in some studies ${ }^{15,16)}$, with females showing higher rates than males. It is wellknown that both cellular and humoral immune responses to various antigenic stimuli are higher in females than in males. Accordingly, since HBs antigen is produced by the $\mathrm{HBV}$-infected liver cells themselves, its antigenicity is originally low, but in females who have a superior immune response capacity, a stronger immune response to HBs antigen can be induced more easily in many of them than in males, which may be reflected in sex differences in the immune response after inoculation of the $\mathrm{HB}$ vaccine. Thus, even when $\mathrm{HB}$ vaccine is inoculated into healthy adults, antibody is not produced in $5-10 \%$ of them; and in patients with renal insufficiency, antibody is not produced in about $40 \%$ of them ${ }^{9,20,21)}$. In the results obtained by the authors, $8.2 \%$ were non-responders, and besides $15.4 \%$ were weak responders, in many of whom the PHA method of antibody detection failed, although the RIA method gave a positive result.

Individual differences in immune response to $H B$ vaccine may thus reflect age and/or sex. Moreover, there have been reports suggesting an association with HLA antigen ${ }^{23)}$ or states of nutrition ${ }^{22)}$, such as low-protein diet, so that a divergence of causes can be expected. The authors analyzed the peripheral blood lymphocyte subpopulations in subjects inoculated with $\mathrm{HB}$ vaccine, but a significant relationship between the HBs antibody response and abnormality of the immune system could not be demonstrated. However, the finding that the $\mathrm{OKT} 4^{+} / \mathrm{OKT}^{+}$cell ratio was low in $36.4 \%$ of the non-responders, which was clearly higher than the $13.7 \%$ in good responders, suggests some relationship between the antibody response to $\mathrm{HB}$ vaccine and imbalance of the immune control system.

While ordinary vaccines are manufactured with cultured materials, $\mathrm{HB}$ vaccines differ in that they are manufactured from human blood as the starting material, since a method for the culturing of hepatitis B virus has not yet been fully established. Accordingly, the possibility of contamination by human plasma components, hepatitis B virus, non-A and non-B hepatitis virus and other slow viruses cannot be denied. The authors examined the blood before and after inoculation of the same vaccine for changes in levels of antibodies to mycoplasmas and 11 kinds of viruses selected at random, and found none showing significant changes. Contamination of foreign viruses and mycoplasmas was therefore considered negative, and its safety to be vary high.

The side effects appearing after inoculation of $\mathrm{HB}$ vaccine included, like the findings of other researchers ${ }^{15}, 16$ ), sore arm, fatigue, a feverish feeling, headache, induration and nausea at low incidence, but there was no serious allergic reaction or shock. In general, these side effects were increased in incidence in accordance with an increased volume of the inoculum, Szmuness et al. ${ }^{12)}$ and Crosnier et al. ${ }^{21)}$, respectively reported the incidence of low-grade fever, sore arm, skin rashes, nausea, vomitting and faigue to be $24.3 \%$ 
and $17 \%$. Since they made it clear, however, that there was no significant difference between the vaccine-inoculated group and the control group, these side effects may not represent true symptoms due to the $\mathrm{HB}$ vaccine. Thus, with the HB vaccines now available on the market, the possibility of particularly troublesome side effects occurring may be minimal, even though the ingredients of the HBs antigen or the manufacturing methods vary somewhat.

It is important to specify clearly the period of duration of the antibody level induced by inoculation of $\mathrm{HB}$ vaccine, for effective prophylaxis against infection with $\mathrm{HBV}$ using the vaccine. Although it was presumed in some initial re$\operatorname{search}^{9,24)}$ that a value of over $10 \mathrm{IU} / 1$, which was considered the minimal protective antibody level, might persist for 5 years, several reporters ${ }^{25-27)}$ have stated that their observed levels rapidly decreased or disappeared, in spite of these presumptions. It may be said in any event that, for good prophylaxis against infection with $\mathrm{HBV}$ due to a little contamination of HBs antigen-postive blood, it is necessary to maintain an antibody level which is detectable by the PHA method.

When the cut-off index with the RIA method is reduced to below 10, additional immunization must be conducted. In the present results obtained after the third phase test, it was clear that, despite the limited number of subjects, the majority of low responders or weak responders in whom antibody was induced by inoculation of the vaccine became negative at 1-2 years, or the level was reduced to below 10 RIA units, while in high responders (over 50 RIA units), the values were reduced to below 10 RIA units in $4.9 \%$ $(4 / 82)$ at 1 year, and in $39.3 \%(24 / 61)$ at 2 years. Thus, in low responders in whom the HBs antibody level at 1 month after 3 inoculations is below 10 RIA units, an additional inoculation within 6 to 12 months should be considered. Similarly, in low responders in whom the antibody level is within 10-50 RIA units, another examination should be made at 1 year, and if a reduction to below 10 RIA units is observed, another additional inoculation should be considered. Even in high responders, another determination of the antibody level should be made
2 years later, and if a reduction to below 10 RIA units is noted, another additional inoculation may be indicated.

This study was presented in part at the 81 st Annual Scientific Session of the Japanese Society of Internal Medicine, April, 1985.

\section{REFERENCES}

1) Maupas P, Goudeau A, Coursaget P, et al: Immunization against hepatitis B in man. Lancet I: 1367, 1976.

2) Hilleman MR, Buynak EB, Roehm RR, et al: Purified and inactivated human hepatitis $B$ vaccine: Progress report. Amer J Med Sci 270: 401, 1975.

3) Cabasso VJ: In: Workshop on Hepatitis B Vaccine, organized by BOB-NIAID, Bethesda, Maryland, Jan 18,1979 .

4) Reesink HW, Reerink-Brongers EE, Brummelhuis HGJ, et al: The preparation and evaluation of a hepatitis B vaccine in the Netherlands. In: Viral Hepatitis (Vyas GN, Cohon SN and Schmidt R, eds), Franklin Institute Press, Philadelphia, 1978, p 714.

5) Doniach D, Bottazzo GF, Maupas P, et al: Safety of hepatitis $B$ vaccine: No evidence of autoimmunity. Lancet I: 721, 1979.

6) Maupas P, Goudeau A, Coursaget P, et al: Hepatitis $B$ vaccine: Efficacy in high-risk setting, a two-year study. Interviology 10: 196, 1978.

7) Pengloan J, Maupas P, Goudeau A, et al: Efficacy of a vaccine against hepatitis B: Epidemiological data. Proc Eur Dial Transplant Assoc 14: 215, 1977.

8) Maupas P, Goudeau A, Dubois F, et al: Potency and efficacy of $\mathrm{HB}$ vaccine applied to a high-risk population: A five-year study. In: Hepatitis B Vaccine (Maupas P and Guesry P, eds), North-Holland Biomedical Press, Amsterdam, 1981, p 117.

9) Goudeau A, Coursagt P, Barin F, et al: Prevention of hepatitis B by active and passive-active immunization. In: Proc of the 1981 Intl Symp on Viral Hepatitis (Szmuness W, Alter HJ and Maynard JE, eds), Franklin Institute Press, Philadelphia, 1981, p 509.

10) Hilleman MR, Buynak EB, McAleer WJ, et al: Hepatitis $A$ and hepatitis $B$ vaccines. In: Proc of the 1981 Intl Symp on Viral Hepatitis (Szmuness W, Alter $\mathrm{HJ}$ and Maynard JE, eds), Franklin Institute Press, Philadelphia, 1981, p 385.

11) Szmuness W, Stevens CE, Zang EA, et al: Hepatitis $B$ vaccine: A controlled clinical trial in homosexual men. In: Proc of the 1981 Intl Symp on Viral Hepatitis (Szmuness W, Alter HJ and Maynard JE, eds), Franklin Institute Press, Philadelphia, 1981, p 467.

12) Szmuness W, Stevens CE, Harley EJ, et al: Hepatitis $B$ vaccine: Demonstration of efficacy in a controlled 
clinical trial in a high-risk population in the United States. New Eng J Med 303: 833, 1980.

13) McAuliffe VJ, Purcell RH, Gerin JL, et al: Current status of the NIAID hepatitis B vaccines. In: Proc of the 1981 Intl Symp on Viral Hepatitis (Szmuness W, Alter HJ and Maynard JE, eds), Franklin Institute Press, Philadelphia, 1981, p 425.

14) Oda T, Suzuki H, et al: Safety and efficacy of the vaccine produced by the Hepatitis B Vaccine Research Committee of the Japanese Ministry of Health and Welfare. Acta Hepatol Japon 24: 88, 1983.

15) Suzuki $H$ and the Research Group of the Hokken HB Vaccines: Phase III study on hepatitis $B$ vaccine (Hokken). Kan-Tan-Sui 9: 141, 1984.

16) Ichida $F$ and the Research Group of the Green Cross $\mathrm{HB}$ Vaccines: Clinical evaluation of $\mathrm{HB}$ vaccine inoculation test (phase III). Kan·Tan·Sui 9: 463, 1984.

17) Hollinger FB, Adam E, Heiberg D, et al: Response to hepatitis B vaccine in a young adult population. In: Proc of the 1981 Intl Symp on Viral Hepatitis (Szmuness W, Alter HJ and Maynard JE, eds), Franklin Institute Press, Philadelphia, 1981, p 451.

18) Szmuness W, Stevens CE, Harley EJ, et al: The immune response of healthy adults to a reduced dose of hepatitis B vaccine. Med Virol 8: 123, 1981.

19) Krugman S, Holley HP, Davidson JM, et al: Immunogenic effect of inactivated hepatitis $B$ vaccine: Comparison of $20 \mu \mathrm{g}$ and $40 \mu \mathrm{g}$ doses. J Med Virol 8:
$119,1981$.

20) Crosnier J, Jungers P, Courouce AM, et al: Randomized placebo-controlled trial of hepatitis B surface antigen vaccine in French hemialysis units. II. Hemodialy sis patients. Lancet I: 797, 1981.

21) Crosnier J, Jungers P, Courouce AM, et al: Randomized placebo-controlled tiral of hepatitis B surface antigen vaccine in French hemodialysis units. I. Medical staff. Lancet I: 455, 1981.

22) Kenny JF, Pangburn PC and Trial G: Effect of estradiol on immune competence: In vivo and in vitro studies. Infect Immun 13: 448, 1976.

23) Hashimoto E, Obata $H$, Nakanishi $T$, et al: HLA antigens and anti-HBs response to hepatitis $B$ vaccine. Acta Hepatol Japon 26: 157, 1985.

24) Szmuness W, Stevens CE, Zang EA, et al: A controlled clinical trial on the efficacy of the hepatitis $B$ vaccine (Hepatavax B): A final report. Hepatolgoy 5: $377,1981$.

25) Hadler SC, Francis DP, Thomson SE, et al: Longterm efficacy of hepatitis B vaccine. In: Viral hepatitis (Vyas GN, ed), Franklin Institute Press, Philadelphia (in press).

26) Zachoval R, Jily W, Lorbeer B, et al: Passive-active imjunization against hepatitis B. J Infect Dis 150: $112,1984$.

27) Jilg W, Schmidt M, Deinhardt F, et al: Hepatitis B vaccination: How long does protection last? Lancet I: 458,1984 . 